\title{
The Werther Effect in Children: A Case Report
}

\author{
Amraouza K*, Ennazk S, Akebour K, EL Barmaki N, Adali I, Manoudi F, Asri F
}

Research Team for Psychiatry and Mental Health, University Department of Psychiatry, Mohammed VI University Hospital center, Marrakech, Morocco

DOI: $10.36347 /$ simcr.2020.v08i03.024

| Received: 24.02.2020 | Accepted: 07.03.2020 | Published: 17.03.2020

*Corresponding author: Amraouza Khadija

Abstract

The Werther effect, or suicidal contagion via the media, is a serious phenomenon, that is underestimated and little studied among children. Our case, an eight years old girl, who did a suicide attempt by hanging, following a similar scene on television, brought us to do a review on this subject. In fact, children would be more vulnerable than adolescents and adults facing media influence. This is due to the fact that imitation and identification phenomena are more important during early stages of development. However, means of communication can be used as protective means against suicide, by involving parents and community.

Keywords: Werther effect, child, suicide, media.

Copyright @ 2020: This is an open-access article distributed under the terms of the Creative Commons Attribution license which permits unrestricted use, distribution, and reproduction in any medium for non-commercial use (NonCommercial, or CC-BY-NC) provided the original author and source are credited.

\section{INTRODUCTION}

The Werther effect refers to suicide undirect contagion through media. It refers to Goethe's novel " the sorrows of young Werther" in which the hero commits suicide which would have caused a wave of suicide among readers [1]. We know that imitation is essential in the development of individuals. This leads us to questioning the Werther effect among children, which is precisely the case of our patient, a child of 8 , who committed suicide attempt by hanging after seeing a similar scene on television. This led us to making a review about this topic.

\section{Clinical Case}

Our patient is an 8 year old child. She was brought to the pediatric emergency department for asphyxia following a hanging suicide attempt. Resuscitation measures saved the child's life, but she presented post-anoxic encephalopathy with severe neurological sequelae: aphasia, quadriplegia and neurocognitive disorders.

The accident took place at home. The child was watching a soap opera on television with her mother. She saw a violent scene: an important figure made a suicide attempt by hanging. After the episode ended, the child retired to her room. Moments later, she was discovered by her sister, hanging from the window by a scarf.
The family interrogation did not reveal a history of psychiatric disorders. The child did not show any change in behavior during the period preceding the suicide attempt. Her functioning was normal at school and at home. She was always first in her class. She was well integrated with her peers. She had no problems with her parents, or with her siblings. There was no specific event or notion of trauma. We did not note any elements pointing towards a mood disorder or any other mental disorder. The whole family was shocked by the act committed by our patient and could not find any explanation for it.

\section{DiscuSSION}

Suicidal behavior is a global public health problem. Young people are the most affected and suicide is now the second leading cause of death among 15-19 year olds [2]. According to statistics from the World Health Organization (WHO), the global average suicide rate among people under the age of 14 is estimated at $0.59 / 100,000$. This makes it the lowest rate by age [2]. Child suicide therefore remains a relatively rare but dramatic phenomenon [3]. It has a lasting impact on families and communities and is probably underestimated.

The suicide attempt is the conduct aiming at killing oneself without succeeding [4]. However, the concept of death is not understood by the child in the same way as by the adult [5]. Numerous studies conclude that the idea of irreversibility in death is 
acquired only around the age of 9 years [6]. The maturity of this concept also depends on the level of cognitive and emotional development of the child and not only on the chronological age [5]. Thus, the study by Mishara et al. [7] shows that at the age of 8 years, $87 \%$ of children know what suicide is. But it's only between 10 and 12 years that $100 \%$ are aware. Berthod et al. [8], for their part, consider that it is not necessary to have a completed representation of death to want to give it to yourself.

Therefore, suicidal acts in children are less often planned and suicidal intentionality less marked than in adolescents or adults, as the study by Dervic et al. shows. [9]. He is generally impulsive and reactive to a life event which most often seems harmless [5]. Suicidal behavior is also characterized by the low proportion of psychiatric disorders found compared to an adolescent or adult population [5].

Another specificity to take into account is the phenomenon of imitation and identification made by children [5]. Indeed, several authors emphasize the major influence of the suicidal behavior of a member of the child's entourage and especially that of the media [10]. We know that among the youngest, the distinction between reality and imagination is not yet perfectly established, which makes the influence of television and the media even more significant for this population [11].

Our case therefore illustrates the danger of the Werther effect, or suicidal contagion via the media, in children. The literature review, conducted by Sisask et al., showed a significant association between media coverage of suicidal behavior, real or fictitious, and suicidal behavior [12]. Contagion is therefore a precipitating factor for suicide and is more frequent in children and adolescents [13].

Nowadays, access to the media is increasingly important and easy for children: television, video games, internet.... Preventing suicide in children can also go through these channels.

The Papageno effect is the protective effect of the means of communication on suicidal behavior. Studies of this effect on children are rare but represent an interesting field of research [14]. Niederkrotenthaler's team has shown that the portrayal in the media of people with suicidal thoughts but without suicidal behavior was negatively correlated with suicide rates, all ages combined [15]. In this sense, Biddle's hypothesis states that the impact of the media (wisely used) in the prevention of suicide would exceed their inductive effect [16]. The role of parents and childcare professionals in all fields is essential in the prevention process. They play a key role in raising awareness, supporting and protecting children from the harmful effects of the media.

\section{CONCLUSION}

The case of our patient allowed us to draw attention to the Werther effect in children which is a dangerous phenomenon that is still much underestimated, and to make us think of the means of prevention to protect young people who represent our future.

\section{REFERENCES}

1. Amitai $\mathrm{M}$ and Apter A. Social aspects of suicidal behavior and prevention in early life: a review. International journal of environmental research and public health.2012;9(3), 985-994.

2. World Health Organization (WHO) [Internet]. http://www.who.int/mental_health/prevention/suicide/co untr y_reports/en/index.html

3. Vandevoorde J. Le geste suicidaire chez l'enfant: mesure du phénomène, caractéristiques épidémiologiques et recommandations de base. Journal de Pédiatrie et de Puériculture.2015;28(4), 197-204.

4. Agence Nationale d'Accréditation et d'Evaluation en Santé. Prise en charge hospitalière des adolescents après une tentative de suicide. Recommandations professionnelles. Paris: ANAES. 1998, 44 p.

5. Delamare C, Martin C. Tentatives de suicide chez l'enfant de moins de 13 ans. Neuropsychiatrie de l'enfance et de l'adolescence. 2007; 55: 41-51.

6. Hanus M. La formation de l'idée de mort chez l'enfant. In : Les deuils dans la vie, deuils et séparations chez l'adulte et l'enfant. Éds Maloine; 1994: 252-64.

7. Mishara B. Conceptions de la mort et du suicide chez l'enfant : recherche empirique et implication pour la prévention du suicide. PRISME. 1995;5(4):499-508.

8. Berthod C, Giraud C, Gansel Y, Fourneret P, Desombre H. Tenta-tives de suicide chez 48 enfants âgés de 6 à 12 ans. Arch Pediatr.2013;20(12):1296-305.

9. Dervic K, Brent DA, Oquendo MA. Completed Suicide in Childhood. Psychiatr Clin North Am. 2008 ;31(2): 271-91.

10. Bush EG, Pargament KI. A quantitative and Qualtitive Analysis of Suicidal Preadolescent Children and Their Families. Child Psychiat Human Dev. 1995; 25 (4): 241 52.

11. Gould MS, Shaffer D. The Impact of Suicide in Television Movies. N Engl J Med. 1986; 11: 690-4.

12. Sisask M, Värnik A. Media roles in suicide prevention: a systematic review. Int J Environ Res Public Health. Janv. 2012 ; 9(1): 123-138.

13. Gould MS. Suicide and the media. Ann N Y Acad Sci. Avr. 2001; 932: 200-224.

14. Lucie Baux Cazal. Les conduites suicidaires et leur prévention chez l'enfant de moins de 13 ans: une revue de la littérature internationale. Médecine humaine et pathologie. 2015. dumas-01166257

15. Niederkrotenthalert, Voracek M, Herberth A. Role of media reports in completed and prevented suicide: Werther v. Papageno effects. $\mathrm{Br} \mathrm{J}$ Psychiatry. 2010;197(3): 234-243.

16. Biddle L, Donovan J, Hawton K. Suicide and the internet. BMJ. Avr. 2008; 336(7648): 800-802. 